\title{
Small-scale variability in geomorphological settings influences mangrove-derived organic matter export in a tropical bay
}

\author{
Geraldina Signa $^{1,2}$, Antonio Mazzola ${ }^{1,2}$, James Kairo ${ }^{3}$, and Salvatrice Vizzini ${ }^{1,2}$ \\ ${ }^{1}$ Department of Earth and Marine Sciences, University of Palermo, via Archirafi 18, Palermo, Italy \\ ${ }^{2}$ CoNISMa, Piazzale Flaminio 9, Roma, Italy \\ ${ }^{3}$ Kenya Marine and Fisheries Research Institute, P.O. Box 81651, Mombasa, Kenya \\ Correspondence to: Geraldina Signa (geraldina.signa@unipa.it)
}

Received: 19 July 2016 - Discussion started: 24 August 2016

Revised: 29 November 2016 - Accepted: 10 January 2017 - Published: 9 February 2017

\begin{abstract}
Organic matter (OM) exchanges between adjacent habitats affect the dynamics and functioning of coastal systems, as well as the role of the different primary producers as energy and nutrient sources in food webs. Elemental $(\mathrm{C}, \mathrm{N}$, $\mathrm{C}: \mathrm{N})$ and isotope $\left(\delta^{13} \mathrm{C}\right)$ signatures and fatty acid (FA) profiles were used to assess the influence of geomorphological setting in two climatic seasons on the export and fate of mangrove OM across a tidally influenced tropical area, Gazi Bay (Kenya). The main results indicate that tidal transport, along with riverine runoff, plays a significant role in the distribution of mangrove organic matter. In particular, a marked spatial variability in the export of organic matter from mangroves to adjacent habitats was due to the different settings of the creeks flowing into the bay. Kinondo Creek acted as a mangrove retention site, where export of mangrove material was limited to the contiguous intertidal area, while Kidogoweni Creek acted as a "flow-through" system, from which mangrove material spreads into the bay, especially in the rainy season. This pattern was evident from the isotopic signature of primary producers, which were more ${ }^{13} \mathrm{C}$-depleted in the Kinondo Creek and nearby, due to the lower dilution of the dissolved inorganic carbon (DIC) pool, typically depleted as an effect of intense mangrove mineralisation. Despite the trapping efficiency of the seagrass canopy, suspended particulate OM showed the important contribution of mangroves across the whole bay, up to the coral reef, as an effect of the strong ebb tide. Overall, mixing model outcomes indicated a widespread mixed contribution of both allochthonous and autochthonous OM sources across Gazi Bay. Moreover, FAs indicated a notable contribution of brown macroalgae and bacteria in both sediment and suspended pools. These
\end{abstract}

results suggest that ecological connectivity in Gazi Bay is strongly influenced by geomorphological setting, which may have far-reaching consequences for the functioning of the whole ecosystem and the local food webs.

\section{Introduction}

Mangrove forests are known to be among the most productive ecosystems worldwide, with a crucial role in the carbon budget (Alongi, 2014; Dittmar et al., 2006; Kristensen et al., 2008). Indeed, mangroves sequester large amounts of carbon deriving from two main pathways: atmospheric carbon fixation contributing to high aboveground and belowground biomass and carbon input from adjacent terrestrial and marine systems (Alongi, 2014). However, a considerably large amount of mangrove-derived carbon in the form of leaves, particulate detritus and dissolved organic and inorganic matter is exported to adjoining ecosystems, subsidising coastal waters and influencing nutrient biogeochemical cycling (Dittmar et al., 2006; Duarte and Cebrián, 1996).

The long-standing scientific debate regarding the fate of the high mangrove productivity has led to various theories and paradigms. With the "outwelling hypothesis", Odum and Heald (1972) first suggested that leaf detritus exported from mangrove forests would represent an important trophic source contributing to secondary production in adjacent offshore areas. While a few studies have confirmed this hypothesis (Dittmar et al., 2001; Lugendo et al., 2007), others have reported limited evidence that exported mangrove detritus subsidises offshore food webs (Lee, 1995). More recently, 
a tight interlinkage between mangroves and adjacent seagrasses has been found in many geographical areas (Bouillon et al., 2003, 2007; Gillis et al., 2014; Kennedy et al., 2004), leading to the "inwelling hypothesis", whereby the tidal import of seagrass litter to mangrove forests and its contribution to the carbon budget would also be significant (Bouillon et al., 2003; Walton et al., 2014).

According to the "environmental setting hypothesis" (Twilley, 1985), geomorphological features and hydrology are the most important abiotic factors affecting the exchange of mangrove material across ecosystem boundaries (Adame and Lovelock, 2011; Lee, 1999). In particular, the combined control of river discharge (magnitude and frequency), tidal amplitude, rainfall, and wave action is reported to influence the exchange of material across boundaries in estuarine mangrove systems. Tropical rivers are one of the main vectors of carbon from terrestrial to coastal areas (Bouillon and Connolly, 2009), especially when the flushing rate is amplified by high rainfall (Dittmar et al., 2001). Otherwise, low rainfall and freshwater runoff have been related to reduced mangrove outwelling (Walton et al., 2014). Tidal amplitude, frequency and direction (flood vs. ebb tide) influence cross-habitat connectivity in the tropical coastal seascape, through bidirectional movements of water and nekton across wide spatial scales (Adame and Lovelock, 2011).

Bulk elemental composition ( $\mathrm{C}, \mathrm{N}$ and $\mathrm{C}: \mathrm{N}$ ratio) and carbon stable isotope (SI) signature $\left(\delta^{13} \mathrm{C}\right)$ are widely used to trace organic matter origin and fate in coastal systems (e.g. Bouillon et al., 2003; Vizzini and Mazzola, 2008; Walton et al., 2014). This is because $\mathrm{C}: \mathrm{N}$ ratio and $\delta^{13} \mathrm{C}$ composition of the different organic matter sources contributing to sedimentary and suspended particulate pools are often markedly distinct (Bouillon et al., 2008; Lamb et al., 2006). Nevertheless, this dual approach has a number of constraints, such as the lowering effect of decomposition on $\mathrm{C}: \mathrm{N}$ ratio (Bosire et al., 2005; Dunn et al., 2008; Kennedy et al., 2004) or the potential overlapping of basal source isotopic signatures (Fry and Sherr, 1989), which may complicate inferences in coastal areas where autochthonous and allochthonous materials mix. The simultaneous use of other complementary tracers, such as fatty acids (FAs), may significantly improve the determination of OM sources in aquatic systems (Alfaro et al., 2006; Dunn et al., 2008) and their trophic pathways, both detrital and grazing pathways, in complex systems (Kelly and Scheibling, 2012). Indeed, FAs are particularly well suited to distinguishing among a wide range of organic matter sources (i.e. dinoflagellates, diatoms, mangroves, macroalgae, seagrasses, bacteria) because of their high biological specificity and their structural and trophic stability (Kelly and Scheibling, 2012; Meziane et al., 2006).

Gazi Bay in Kenya is a tropical area characterised by high cross-habitat contiguity. The bay is fringed by a dense mangrove forest and the seabed covered with seagrass beds mixed with patchy macroalgae. Two tidal creeks, of which only one receives riverine freshwater input, intersect the man- grove forest. Rainfall seasonality exerts a marked influence on runoff magnitude (Kitheka, 1997). Earlier studies in Gazi Bay reported a marked outwelling of mangrove-derived material up to the adjacent seagrass beds (Bouillon et al., 2007; Hemminga et al., 1994) and also a reversed inwelling of seagrass material that contributes to a tight linkage between these two contiguous habitats (Hemminga et al., 1994). In contrast, adjacent coral reefs have been found to be fairly isolated from the inshore habitat (Hemminga et al., 1994). However, previous investigations were limited to only a few parts of the bay or only one climatic season, and were conducted exclusively through a qualitative analysis of stable isotopes. Moreover, only tidal pumping was considered as the main driver of outwelling and inter-habitat connectivity. In contrast, the role of small-scale variability in the geomorphology of the bay, in terms of tidal creek length, depth and freshwater runoff on mangrove export and cross-habitat organic matter exchange, has never been assessed. Given the importance and ecological implications of mangrove export along the river-bay-coral reef-open sea continuum, a higher spatial resolution, combined with a conjoint analytical approach and a quantitative data elaboration, provides more detailed and complete quantitative information.

The main goal of this study was to assess the fate of mangrove-derived organic matter, the dominant terrestrial source in Gazi Bay (Bouillon et al., 2007; Neukermans et al., 2008), in relation to the small-scale variability in geomorphological settings of the area, using combined elemental, isotopic and fatty acid analyses. In particular, following a preliminary characterisation of primary producers, sediment (SOM) and suspended particulate organic matter (SPOM), we estimated the contribution of dominant primary producers to SOM and SPOM pools based on quantitative (isotope mixing models) and semi-quantitative (fatty acid profiles) approaches. This allowed for assessment of the export of mangrove-derived organic matter towards adjacent habitats in relation to the different geomorphological settings of the bay in the two main climatic seasons: dry and rainy.

\section{Materials and methods}

\subsection{Study area and sample collection}

Gazi Bay $\left(4^{\circ} 25^{\prime} \mathrm{S}, 39^{\circ} 30^{\prime} \mathrm{E}\right)$ is a $\sim 10 \mathrm{~km}^{2}$ shallow semienclosed marine ecosystem on the southern Kenyan coast (Fig. 1). In the northern part it is fringed by a $\sim 6 \mathrm{~km}^{2}$ mangrove forest, while in the southern part it is sheltered from the Indian Ocean by shallow coral reefs (max depth: $10 \mathrm{~m}$ ). Kidogoweni and Kinondo tidal creeks flow through the mangrove forest into the upper part of the bay. Kinondo Creek is shorter and shallower than Kidogoweni $(2500 \mathrm{~m}$ long and $1-2 \mathrm{~m}$ deep vs. $4500 \mathrm{~m}$ long and $2-3 \mathrm{~m}$ deep) and lacks direct freshwater input, except for limited groundwater seepage (Kitheka et al., 1996). Kidogoweni Creek receives freshwa- 


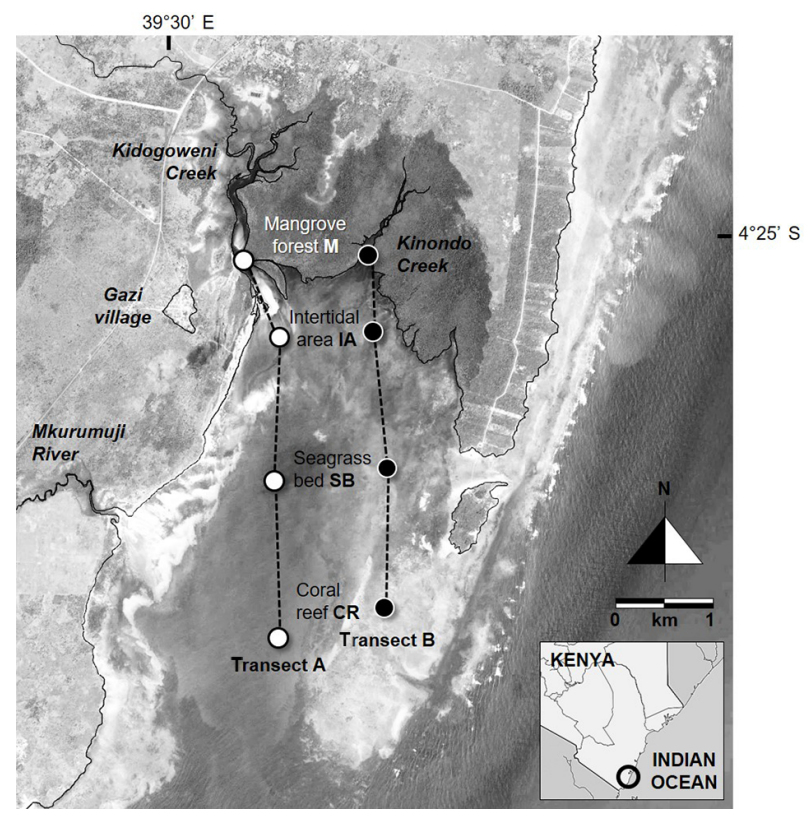

Figure 1. Gazi Bay. Sampling stations lying along two land-tosea transects are shown: mangrove forest (M), intertidal area (IA), seagrass bed (SB), and coral reef (CR). Transect A (white circles) corresponds to Kidogoweni Creek; transect B (black circles) corresponds to Kinondo Creek.

ter input from the semiperennial Kidogoweni River. A third freshwater input, the Mkurumuji River, discharges into the southern part of the bay with high flow rates (max flow: $16.7 \mathrm{~m}^{3} \mathrm{~s}^{-1}$; Kitheka et al., 1996). Sugar plantations are diffuse in the area surrounding the whole bay; hence, their runoff might flow into the watercourses. The tide is semidiurnal, ranging from $0.5 \mathrm{~m}$ at neap tide to $4.0 \mathrm{~m}$ at high spring tide (Kitheka et al., 1996). Tidal currents are faster in the creeks than in the southern part of the bay, and ebb flows are stronger than flood flows (Kitheka, 1997). Two main climatic seasons and a bimodal rainfall distribution characterise the area: a distinct dry season (January-February) is followed by two rainy seasons - the first is long and intense (April-August) and the second is shorter and weaker (October-November).

The dominant mangrove species along the creek fringes at Gazi Bay are Rhizophora mucronata, Ceriops tagal, Sonneratia alba and Avicennia marina (Hemminga et al., 1994; Neukermans et al., 2008). Seagrass beds mixed with macroalgae cover both the creeks and the bay up to the seaward mouth (Githaiga et al., 2016). Thalassodendron ciliatum, Cymodocea serrulata, $C$. rotundata and Enhalus acoroides are among the most abundant seagrass species, while Sargassum binderi, Dictyota cervicornis, and Turbinaria conoides are among the most abundant brown and Gracilaria corticata and Hypnea cornuta among the most abundant red macroalgae.
Sampling was carried out in February and July 2009, during the dry and rainy seasons, respectively, in four stations: a mangrove forest (M), intertidal area (IA), seagrass bed (SB) and coral reef (CR), situated along two land-to-sea transects, corresponding to the two tidal creek mouths, Kidogoweni (A) and Kinondo (B) (Fig. 1). In both seasons, sampling was carried out at spring tides. At each station, three replicates of surface water and sediment were collected using $5 \mathrm{~L}$ bottles and hand corers (length: $20 \mathrm{~cm}$; inner diameter: $4 \mathrm{~cm}$ ) respectively. The most abundant organic matter sources (senescent yellow mangrove leaves, seagrass shoots and macroalgae thalli) were collected by hand at each station, except for mangrove leaves, which were sampled only in the mangrove stations. Zooplankton were captured by towing a net $(335 \mu \mathrm{m}$ mesh) for $15 \mathrm{~min}$ at constant speed in each station. All samples were kept cool and dark in a cool box upon arrival at the laboratory.

\subsection{Laboratory activities and analytical procedures}

Surface water was pre-filtered using a $200 \mu \mathrm{m}$ net and then filtered onto precombusted $\left(450^{\circ} \mathrm{C}, 4 \mathrm{~h}\right)$ Whatman $\mathrm{GF} / \mathrm{F}$ filters to collect suspended particulate organic matter (SPOM). The first centimetres $(\sim 5 \mathrm{~cm})$ of sediment cores were sliced, homogenised and subsampled for subsequent analysis of sedimentary organic matter (SOM). After species identification, mangrove and seagrass leaves and macroalgae were quickly rinsed to remove any extraneous material, and, when present, epiphytes were scraped. Zooplankton samples were sorted under a stereo microscope (10 to $40 \times$ magnification). Subsamples for elemental and isotopic analyses were dried at $60^{\circ} \mathrm{C}$ to constant weight and ground to a fine powder using a micro-mill (Retsch MM200). Filters and sediments for carbon stable isotope analysis were acidified $(\mathrm{HCl}, 2 \mathrm{~N})$ drop by drop to remove carbonates, washed and dried again. Subsamples for fatty acid analysis were frozen $\left(-80^{\circ} \mathrm{C}\right)$, freezedried (ALPHA 1-4 LD plus, Martin Christ) and ground into a powder using a micro-mill (Retsch MM200). Ground samples were kept at $-80^{\circ} \mathrm{C}$ until analysis.

An elemental analyser (Thermo Flash EA 1112) was used for the determination of total carbon and nitrogen, and connected to an isotope ratio mass spectrometer (Thermo Delta Plus XP) for $\delta^{13} \mathrm{C}$ analysis. $\delta^{13} \mathrm{C}$ was expressed in relation to Pee Dee Belemnite international standard, and defined as

$\delta^{13} \mathrm{C}=\left[\left(R_{\text {sample }} / R_{\text {standard }}\right)-1\right] \times 10^{3}$,

where $R$ is the ${ }^{13} \mathrm{C} /{ }^{12} \mathrm{C}$ ratio. Analytical precision based on the standard deviation of replicates of internal standards (International Atomic Energy Agency IAEA-CH-6) was 0.2\%o.

Lipids were extracted from suspended particulate organic matter collected in filters, surface sediment and primary producers using a distilled water / methanol / chloroform solvent mixture $(1: 2: 1 \mathrm{v} / \mathrm{v} / \mathrm{v})$ with $0.01 \%$ BHT (butylated hydroxyl toluene) to prevent lipid oxidation, following a modified version of the Bligh and Dyer (1959) method. Samples 


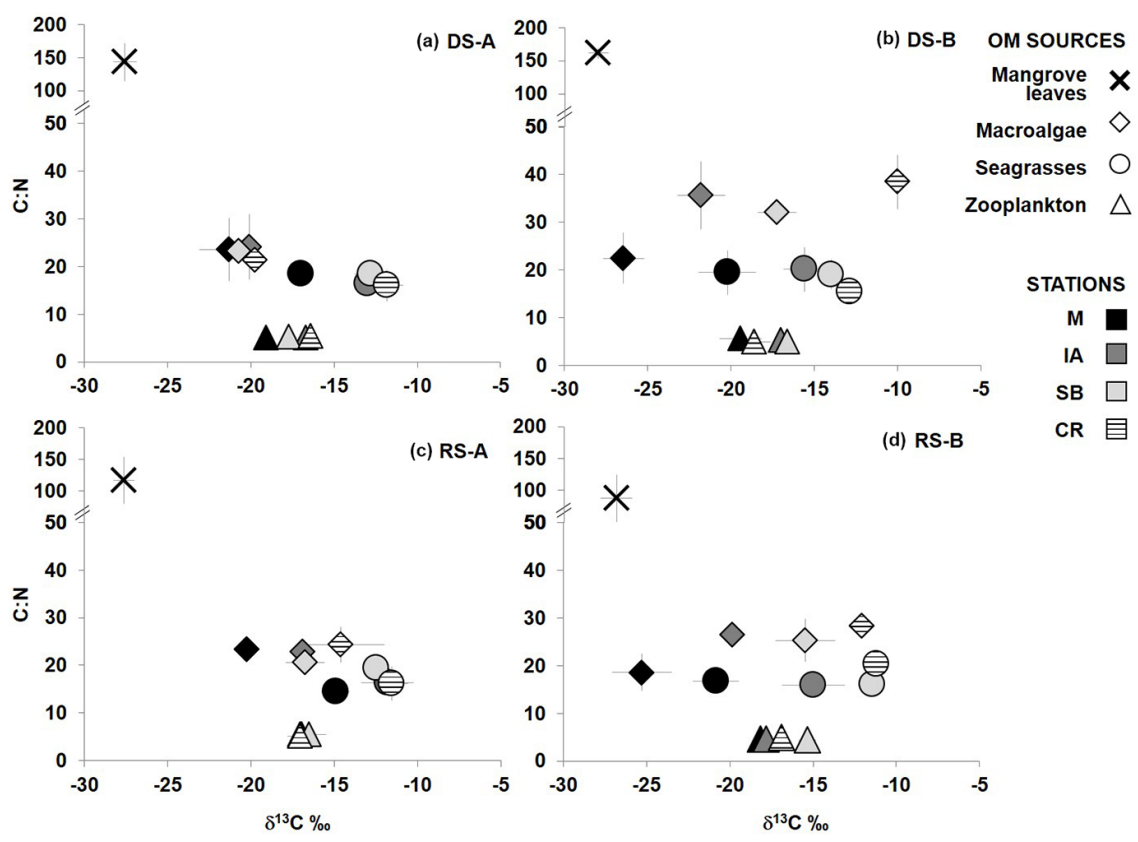

Figure 2. $\mathrm{C}: \mathrm{N}$ ratio versus $\delta^{13} \mathrm{C}(\%$ ) of organic matter sources from the four sampling stations (mangrove forest $\mathrm{M}$ in black, intertidal area IA in dark grey, seagrass bed SB in light grey, coral reef CR in stripes) along transects A and B in dry (DS) and rainy seasons (RS). Mangroves (cross), macroalgae (diamond), seagrasses (circle) and zooplankton (triangle).

with the extracting mixture were sonicated to extract lipids and then centrifuged to separate the lipid phase from the aqueous phase. Afterwards, the lipid extract was subjected to acid-catalysed transesterification with methanolic hydrogen chloride to obtain fatty acids (FAs). FAs were then analysed as methyl esters (FAME) by a gas chromatograph (GC-2010, Shimadzu) equipped with a BPX-70 capillary column (30 m length; $0.25 \mathrm{~mm}$ ID; $0.25 \mu \mathrm{m}$ film thickness) and with a flame ionisation detector (FID). Peaks were identified using retention times from mixed commercial standards (37FAME and BAME from Supelco; BR1 and QUALFISH from Larodan). For quantification, tricosanoic acid (C23:0) was used as internal standard. Individual FAs were expressed as percentage of total FAs.

\subsection{Data analysis}

Differences in the elemental and isotopic signatures of primary producers (mangroves, red and brown macroalgae, seagrasses) were tested through permutational multivariate analysis of variance (PERMANOVA; PRIMER-E Ltd., Plymouth, UK) carried out on the Euclidean distance matrix calculated from $\mathrm{C}: \mathrm{N}$ and $\delta^{13} \mathrm{C}$ datasets. The following experimental design was used, including the following three orthogonal fixed factors: season (two levels: dry season and rainy season), transect (two levels: A and B) and station (four levels: mangrove forest, intertidal area, seagrass bed and coral reef).
Bayesian mixing models were run five times on $\delta^{13} \mathrm{C}$ data using the software package SIAR (Stable Isotope Analysis in R) (Parnell et al., 2010) to estimate the contribution of each organic matter source to sedimentary and suspended particulate organic matter. Bayesian models circumvent the limitations of classical qualitative approaches by including in the models the high degree of variability and uncertainty inherent in ecological systems (Parnell et al., 2010). The dominant organic matter sources in the area, namely mangroves, macroalgae and seagrasses, were chosen as endmembers for sedimentary organic matter. Oceanic SPOM was not included in the model as a proxy of phytoplankton because of the small proportion of phytoplankton biomass within the POM pool in Gazi Bay (Bouillon et al., 2007). Mangroves, macroalgae, seagrasses and zooplankton were chosen as endmembers for suspended particulate organic matter. No trophic enrichment factor was included in the models, assuming that the isotopic composition of the organic matter sources did not change following their incorporation into SOM and SPOM (Gonneea et al., 2004). PERMANOVA was carried out on the Euclidean distance matrix calculated from the Bayesian mixing model outcomes (mode, mean, upper and lower limits of the 95th credibility interval, five replicates) of each source using the same experimental design as for the elemental and isotopic signatures.

PERMANOVA was also performed to examine differences in FA profile between species within primary producer groups (mangroves, red and brown macroalgae, seagrasses) and among primary producer groups. FAs were resembled 

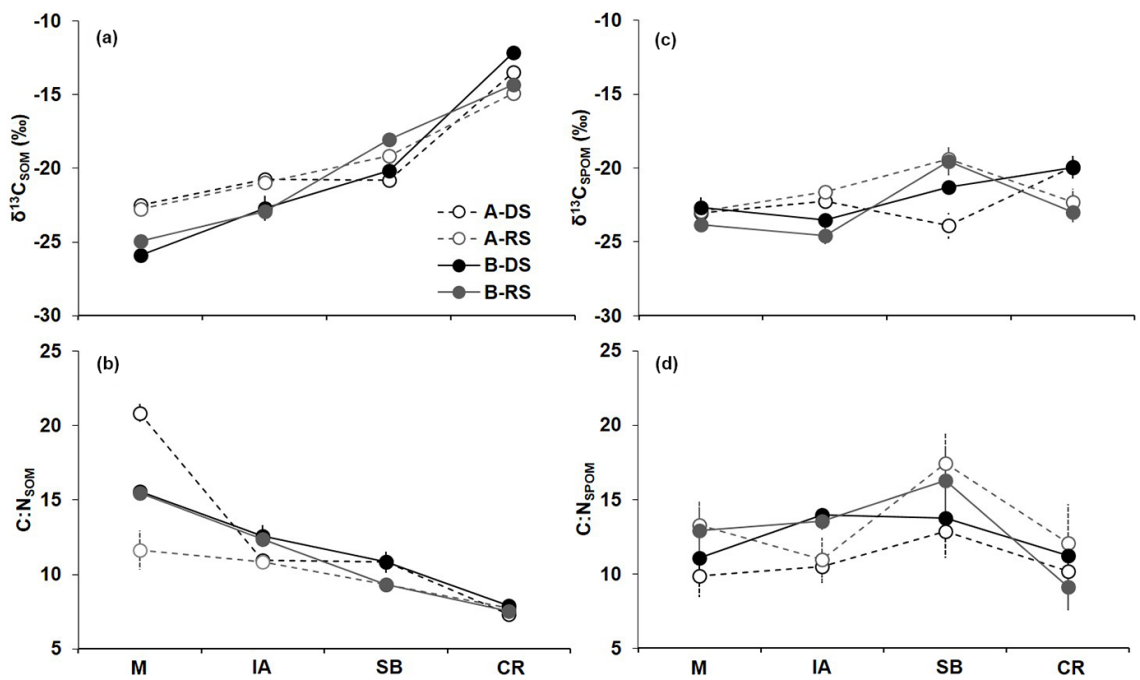

Figure 3. $\delta^{13} \mathrm{C}(\% \circ)$ and $\mathrm{C}: \mathrm{N}$ ratio of sedimentary organic matter (SOM; a, b) and suspended particulate organic matter (SPOM; $\left.\mathbf{c}, \mathbf{d}\right)$ from the four sampling stations (mangrove forest, M; intertidal area, IA; seagrass bed, SB; coral reef, CR). Transects A and B are indicated with open and filled circles respectively. Dry (DS) and rainy seasons (RS) are indicated in black and grey circles respectively.

using Bray-Curtis similarity after arcsine square root function transformation. The analysis of percentage similarity (SIMPER) was used on untransformed data to identify the FAs that contributed more to the similarity within and dissimilarity between primary producer groups (Clarke and Warwick, 2001). Therefore, these FAs were used as indicators of specific primary producer-derived organic matter for sedimentary and suspended particulate material, together with those reported in the current literature.

\section{Results}

\subsection{Isotopic and elemental tracers}

\subsubsection{Primary producers, sedimentary and suspended particulate organic matter}

Mangrove leaves showed the most depleted $\delta^{13} \mathrm{C}$ signatures and the highest $\mathrm{C}: \mathrm{N}$ ratios of all organic matter sources in both transects and seasons (Fig. 2; PERMANOVA: $p<0.05)$. Macroalgae, followed by seagrasses, presented significantly higher $\delta^{13} \mathrm{C}$ than mangroves, and the values increased progressively moving from the mangroves towards the sea. This trend was especially marked along transect B, where also wider $\delta^{13} \mathrm{C}$ ranges were observed, compared to those recorded along transect $\mathrm{A}$. In addition, both macroalgae and seagrasses from the landward stations (M, IA) were significantly more ${ }^{13} \mathrm{C}$-depleted in transect $\mathrm{B}$ than in transect A (PERMANOVA: $p<0.05$ and $<0.01$ for macroalgae and seagrasses respectively). In contrast, stable isotope and elemental ratios of zooplankton were more homogeneous at both spatial and temporal scales (PERMANOVA: $p>0.05$ ). $\delta^{13} \mathrm{C}$ of sedimentary organic matter $\left(\delta^{13} \mathrm{C}_{\mathrm{SOM}}\right)$ increased drastically along the land-to-sea transects (Fig. 3a). $\delta^{13} \mathrm{C}_{\mathrm{SOM}}$ of the landward stations (M, IA) was lower overall in transect $\mathrm{B}$ than in $\mathrm{A}$, while it was more homogeneous in the other stations and showed a marked increase in the coral reefs $(\mathrm{CR})$. Sedimentary $\mathrm{C}: \mathrm{N}$ ratio $\left(\mathrm{C}: \mathrm{N}_{\mathrm{SOM}}\right)$ also showed a marked spatial pattern in the bay, decreasing steadily from mangroves (M) to coral reefs (CR) (Fig. 3b). A striking seasonal difference was observed in the mangrove station of transect A, where the lowest value (10.2) was recorded in the rainy season and the highest (21.5) in the dry. Unlike SOM, $\delta^{13} \mathrm{C}_{\text {SPOM }}$ and $\mathrm{C}$ : $\mathrm{N}_{\text {SPOM }}$ were overall more homogeneous among stations (Fig. 3c, d) except for the highest values recorded in the samples collected in seagrass beds (SB).

\subsubsection{Mixing models}

Bayesian mixing model outcomes provided the ranges of possible contributions (95th percentile intervals) of organic matter sources to sedimentary ( $\mathrm{SOM}$ ) and suspended particulate (SPOM) organic matter. The output of the models is expressed as probability distributions and - although the percentile intervals were wide and overall overlapped, indicating a potential contribution of multiple sources and a nonnegligible level of uncertainty in some cases - their validity is assured because they incorporate error terms (Parnell et al., 2010). Overall, the contribution of mangroves to SOM was high in the whole bay up to the seagrass beds, while it decreased sharply in coral reefs (Fig. 4). In more detail, at multivariate level, the mangrove contribution to SOM was significantly different between stations in both seasons and transects (Table 1). Indeed, along transect B, corresponding to the Kinondo tidal creek, the credibility intervals were par- 


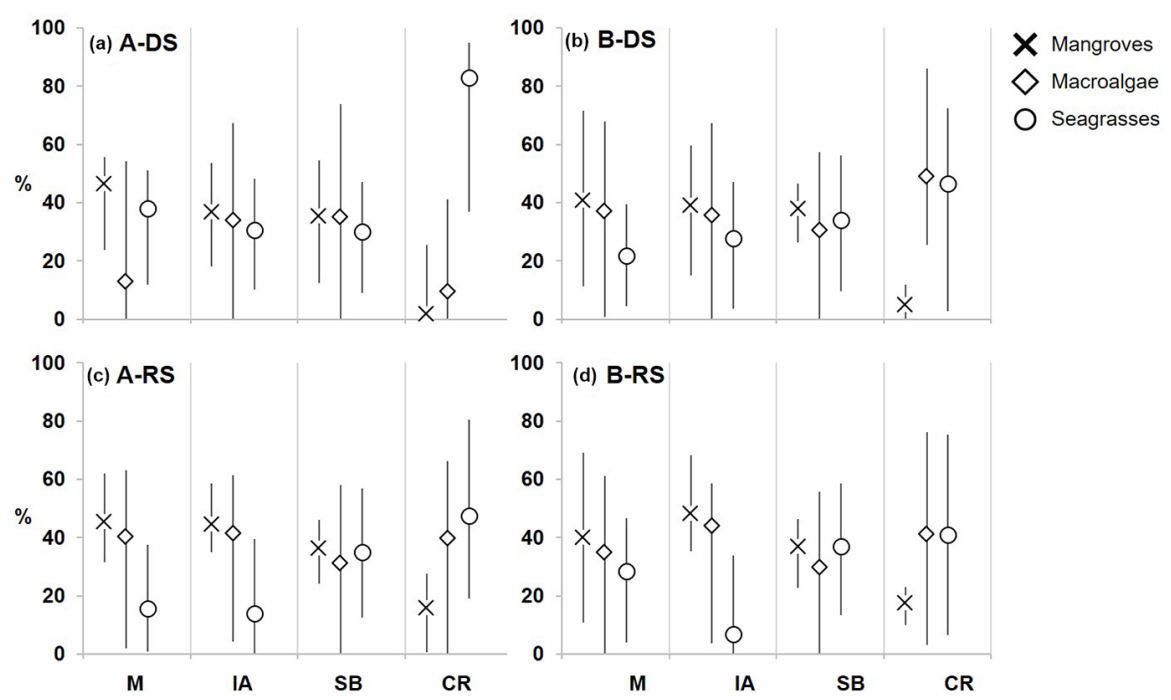

Figure 4. Organic matter source probability of contribution (mode \pm 95 th credibility interval) to SOM in the four sampling stations (mangrove forest, M; intertidal area, IA; seagrass bed, SB; coral reef, CR) along transects A and B in dry (DS) and rainy season (RS). Mangroves (cross), macroalgae (diamond) and seagrasses (circle).
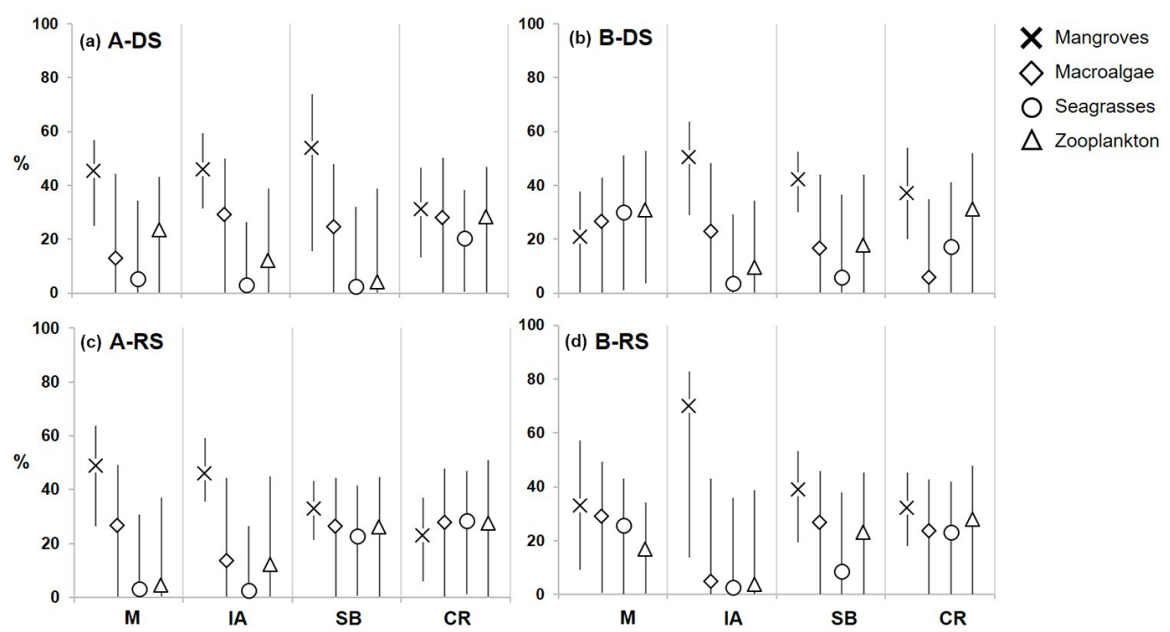

Figure 5. Organic matter source probability of contribution (mode \pm 95th credibility interval) to SPOM in the four sampling stations (mangrove forest, M; intertidal area, IA; seagrass bed, SB; coral reef, CR) along transects A and B in dry (DS) and rainy season (RS). Mangroves (cross), macroalgae (diamond), seagrasses (circle) and zooplankton (triangle).

ticularly wide in both seasons (DS: 11.2-71.4\%; RS: 10.7$69.1 \%$ ) and tended to narrow going seaward. Moreover, the mode values slightly decreased from the mangrove stand (M) up to seagrass beds (SB) (DS: 40.7-37.9\%; RS: 40.1$36.8 \%$ ), except for the peak (48.3\%) recorded in the intertidal area (IA) in the rainy season. In contrast, along transect A, in correspondence of the Kidogoweni tidal creek, both mode values and the credibility intervals showed a slight but significant decrease, more evident in the rainy season than in the dry, and credibility intervals were overall narrower than in the other transect. The contribution of macroalgae and seagrasses to SOM was also significantly different between stations in both seasons and transects (Table 1). Credibility in- tervals were rather wide, and mode values were overall comparable except in coral reefs, where they were higher than in the other stations in all cases (except for the low values of macroalgae in the dry season in transect A).

The contribution of mangrove-derived organic matter to SPOM was important in Gazi Bay up to the coral reefs (Fig. 5), without any relevant seasonal pattern. Along transect $\mathrm{A}$, the mangrove contribution was significantly higher than that of the other sources in the seagrass beds (range: 15.5-73.8\%) and then diminished in CR, becoming comparable to the other sources. Along transect $\mathrm{B}$, mangrove contribution was fairly important in all stations, with a peak in IA $(13.7-82.9 \%)$. 
Table 1. Results of PERMANOVA main tests and pair-wise tests (9999 permutations) for organic matter source contribution to SOM (a) and SPOM (b). df: degree of freedom; MS: mean square; $P($ perm): permutational probability values.

(a) SOM

\begin{tabular}{|c|c|c|c|c|c|c|c|c|c|c|}
\hline \multicolumn{11}{|l|}{ Main test } \\
\hline \multirow[t]{2}{*}{ Source of variation } & \multirow[t]{2}{*}{ df } & \multicolumn{3}{|c|}{ Mangroves } & \multicolumn{3}{|c|}{ Macroalgae } & \multicolumn{3}{|c|}{ Seagrasses } \\
\hline & & MS & Pseudo- $F$ & $P($ perm $)$ & MS & Pseudo- $F$ & $P($ perm $)$ & MS & Pseudo- $F$ & $P($ perm $)$ \\
\hline Season (se) & 1 & 0.26 & 654.9 & 0.0001 & 0.12 & 461.7 & 0.0001 & 0.37 & 2058.9 & 0.0001 \\
\hline Transect (tr) & 1 & 0.01 & 31.5 & 0.0001 & 0.25 & 956.4 & 0.0001 & 0.26 & 1487.1 & 0.0001 \\
\hline Station (st) & 3 & 1.84 & 4653.0 & 0.0001 & 0.07 & 282.0 & 0.0001 & 1.51 & 8456.4 & 0.0001 \\
\hline se $x \operatorname{tr}$ & 1 & 0.01 & 21.7 & 0.0001 & 0.24 & 938.7 & 0.0001 & 0.21 & 1151.8 & 0.0001 \\
\hline se $\mathrm{x} \mathrm{st}$ & 3 & 0.08 & 197.2 & 0.0001 & 0.08 & 302.6 & 0.0001 & 0.13 & 757.7 & 0.0001 \\
\hline $\operatorname{tr} \times s t$ & 3 & 0.11 & 282.4 & 0.0001 & 0.26 & 1010.4 & 0.0001 & 0.20 & 1147.5 & 0.0001 \\
\hline se $x \operatorname{tr} x$ st & 3 & 0.03 & 68.9 & 0.0001 & 0.15 & 594.9 & 0.0001 & 0.11 & 598.3 & 0.0001 \\
\hline Residual & 64 & 0.00 & & & 0.00 & & & 0.00 & & \\
\hline Total & 79 & & & & & & & & & \\
\hline
\end{tabular}

Pair-wise tests: term "se x tr x st" for pairs of levels of factor "station".

All the comparisons resulted significant at $P($ perm $)<0.01$.

\section{(b) SPOM}

\begin{tabular}{|c|c|c|c|c|c|c|c|c|c|c|c|c|c|}
\hline \multicolumn{14}{|l|}{ Main test } \\
\hline \multirow[t]{2}{*}{ Source of variation } & \multirow[t]{2}{*}{ df } & \multicolumn{3}{|c|}{ Mangroves } & \multicolumn{3}{|c|}{ Macroalgae } & \multicolumn{3}{|c|}{ Seagrasses } & \multicolumn{3}{|c|}{ Zooplankton } \\
\hline & & MS & Pseudo- $F$ & $P($ perm $)$ & MS & Pseudo- $F$ & $P($ perm $)$ & MS & Pseudo- $F$ & $P($ perm $)$ & MS & Pseudo- $F$ & $P($ perm $)$ \\
\hline Season (se) & 1 & 0.01 & 107.6 & 0.0001 & 0.01 & 13.0 & 0.0007 & 0.04 & 146.5 & 0.0001 & 0.01 & 22.9 & 0.0001 \\
\hline Transect (tr) & 1 & 0.04 & 522.1 & 0.0001 & 0.06 & 136.6 & 0.0001 & 0.09 & 348.0 & 0.0001 & 0.02 & 35.4 & 0.0001 \\
\hline Station (st) & 3 & 0.51 & 5976.4 & 0.0001 & 0.02 & 41.9 & 0.0001 & 0.24 & 940.1 & 0.0001 & 0.18 & 367.4 & 0.0001 \\
\hline se $x$ tr & 1 & 0.24 & 2813.1 & 0.0001 & 0.02 & 36.9 & 0.0001 & 0.03 & 122.2 & 0.0001 & 0.05 & 96.6 & 0.0001 \\
\hline se $x$ st & 3 & 0.20 & 2372.4 & 0.0001 & 0.09 & 198.8 & 0.0001 & 0.05 & 180.9 & 0.0001 & 0.12 & 244.4 & 0.0001 \\
\hline $\operatorname{tr} \times s t$ & 3 & 0.36 & 4204.5 & 0.0001 & 0.06 & 118.1 & 0.0001 & 0.13 & 531.3 & 0.0001 & 0.04 & 75.1 & 0.0001 \\
\hline se $x \operatorname{tr} x$ st & 3 & 0.05 & 631.8 & 0.0001 & 0.02 & 50.9 & 0.0001 & 0.02 & 61.1 & 0.0001 & 0.01 & 26.6 & 0.0001 \\
\hline Residual & 64 & 0.00 & & & 0.00 & & & 0.00 & & & 0.00 & & \\
\hline Total & 79 & & & & & & & & & & & & \\
\hline
\end{tabular}

Pair-wise tests: term "se x tr x st" for pairs of levels of factor "station".

all the comparisons resulted significant at $P($ perm $)<0.01$ except for the following:

\begin{tabular}{lrlr|lr|l|}
\hline OM source & Term & Stations & $P($ perm $)$ & Stations & $P($ perm $)$ & Stations \\
\hline Macroalgae & DS - A & IA vs. SB & $<0.05$ & IA vs. CR & n.s. & SB vs. CR \\
Seagrasses & RS - B & M vs. CR & n.s. & & & $<0.05$ \\
\hline
\end{tabular}

\subsection{Fatty acids}

\subsubsection{Primary producers}

The different species of primary producers within each group (mangroves, brown and red macroalgae, seagrasses) showed no significant differences in their FA profiles between seasons, transects, and stations (PERMANOVA: $p>0.05$ ). In contrast, there were significant differences among primary producer groups based on their FA profile (PERMANOVA: $\mathrm{df}=3$; MS: 15 076; $p<0.001)$. All pairwise comparisons were also highly significant $(p<0.001)$. Thus, the data of each species within each group were combined (see Table S1 in the Supplement).

Saturated fatty acids (SFAs) were particularly abundant in mangroves and brown and red macroalgae, due to the contribution of 16:0 and 14:0 FAs. Long-chain fatty acids (LCFAs), typical biomarkers of mangroves (Kelly and Scheibling, 2012; Meziane et al., 2006), were particularly abundant in mangrove leaves. Polyunsaturated fatty acids (PUFAs) consisted almost exclusively of $18: 2 \mathrm{n} 6$ and $18: 3$ $\mathrm{n} 3$ FAs in seagrasses and mangroves, and $20: 5 \mathrm{n} 3$ in red macroalgae, while $18: 4 \mathrm{n} 3,20: 4 \mathrm{n} 6$ and $20: 2 \mathrm{n} 6$ were also abundant in brown macroalgae, consistent with the literature (Kelly and Scheibling, 2012, and references therein). Among monounsaturated fatty acids (MUFAs), overall $18: 1 \mathrm{n} 9$, followed by $16: 1 \mathrm{n} 7$, was the most abundant in all primary producers. SIMPER analysis revealed that mangroves differed from the other primary producers mainly in having a higher contribution of LCFAs (see Table S2). Seagrasses and mangroves were also distinguished by $18: 3 \mathrm{n} 3$ and $18: 2 \mathrm{n} 6$, 

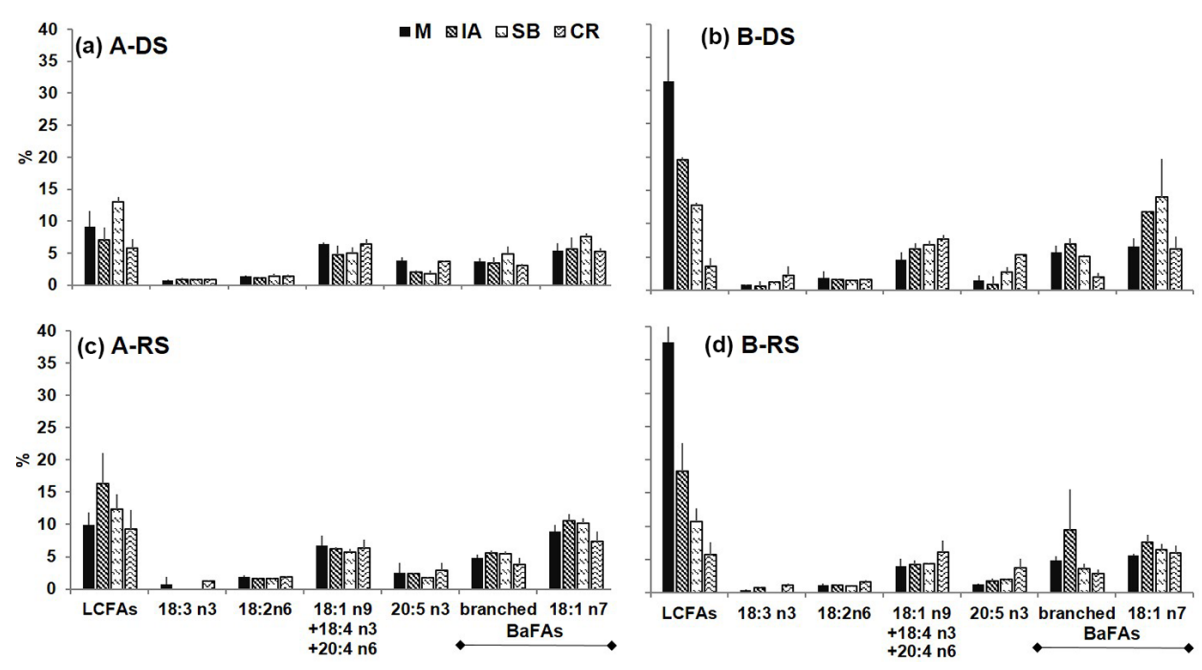

Figure 6. Mean $( \pm \mathrm{SD})$ relative abundance of biomarker FAs (\% of total FAs) in SOM. Selected biomarkers include LCFAs, $18: 3 \mathrm{n} 3$ and $18: 2 \mathrm{n} 6$ for mangroves, $18: 2 \mathrm{n} 6$ and 18:3 n3 for seagrasses, 18:2 n6 for agricultural runoff, 18:1 n9+18:4 n3 + 20:4 n6 for brown macroalgae, $20: 5 \mathrm{n} 3$ for red macroalgae and diatoms, branched FA, and 18:1 $\mathrm{n} 7$ for bacteria.

which contributed more to the seagrass than to the mangrove within-group similarity. Together with the ubiquitous $16: 0$ and $14: 0,20: 5 \mathrm{n} 3$ contributed most to the red macroalgae within-group similarity and to the between-group dissimilarity with the other groups. Likewise, $18: 1 \mathrm{n} 9,18: 4 \mathrm{n} 3,20: 4$ $\mathrm{n} 6$ and $20: 2 \mathrm{n} 6$ characterised brown macroalgae, but only $18: 1 \mathrm{n} 9,18: 4 \mathrm{n} 3$ and $20: 4 \mathrm{n} 6$ contributed most to the dissimilarity with the other primary producers.

\subsubsection{Sedimentary and suspended particulate organic matter}

Forty and 35 individual fatty acids were identified respectively in sedimentary and suspended particulate organic matter. They included (i) straight- and branched-chain saturated FAs (SFAs) dominated by 16:0, 18:0 and long-chain fatty acids (LCFAs); (ii) monounsaturated fatty acids (MUFAs), mainly constituted by $16: 1 \mathrm{n} 7,18: 1 \mathrm{n} 7$ and $18: 1 \mathrm{n} 9$; (iii) polyunsaturated fatty acids (PUFAs) with a high contribution of 18:2 n6, 20:5 n3 and 22:4 n6; (iv) cyclopropyl (CY) FAs; and (v) hydroxyl (OH) FAs (see Tables S3 and S4).

The contribution of LCFAs to SOM was markedly high in the mangrove stands at the Kinondo mouth (transect B), comprising up to $40 \%$ of the total FAs, and progressively decreased toward coral reefs (Fig. 6). In contrast, at the Kidogoweni mouth (transect A), LCFAs were between approximately 5 and $10 \%$ within the mangrove stand and increased in the adjacent habitats (IA, SB), especially in the rainy season. Relative contributions of $18: 3 \mathrm{n} 3$, which can be ascribed to both seagrass and mangrove contribution (Alfaro et al., 2006; Meziane et al., 2006), was rather limited in the whole bay or even null within seagrass beds in the rainy season. The polyunsaturated fatty acid 18:2 n6, which has been often considered a seagrass indicator in tropical systems (Kelly and Scheibling, 2012, and references therein), and is also a tracer of agriculture-derived organic matter (Meziane and Tsuchiya, 2002), showed fairly low and comparable relative contributions in the whole bay. Indicators of brown macroalgae (18:1 n9, 18:4 n3 and 20:4 n6) resulted to be relatively more abundant (5-10\%) than $20: 5$ $\mathrm{n} 3$, which is usually considered a tracer of diatoms (Alfaro et al., 2006; Bachok et al., 2003; Meziane et al., 2006), and also of red macroalgae (Kelly and Scheibling, 2012; results of the present study). It should be mentioned that combined indicators of brown macroalgae and 20:5 n3 showed a similar spatial trend that progressively increases toward the coral reef along transect $\mathrm{B}$ and slightly higher in $\mathrm{M}$ and $\mathrm{CR}$ than in the other stations along transect A (Fig. 6). The relative contribution of bacterial fatty acids (BaFAs) branched 15:0 and $17: 0$, and 18:1 n7 (Kelly and Scheibling, 2012, and references therein) was notable in the whole bay. In particular, $18: 1 \mathrm{n} 7$ was relatively more abundant than branched FAs and, as a general trend, both were higher in IA and SB than in the other stations.

FA profiles of suspended particulate organic matter were also characterised by a large contribution of LCFAs and BaFAs (Fig. 7). In the dry season, they showed a similar spatial trend in both transects, with increasing proportions from mangrove stands to seagrass beds, followed by a decrease in coral reefs. In contrast, in the rainy season, these FAs tended to decrease seaward. Mean contribution of brown macroalgae was also notable and overall similar across the bay especially in the dry season. The contribution of $20: 1$ and $22: 1$, biomarkers of zooplankton (Alfaro et al., 2006; Bachok et al., 2003), was also fairly uniform in the whole bay. The polyunsaturated fatty acids $18: 3 \mathrm{n} 3,18: 2 \mathrm{n} 6$ and 20:5n3 showed 


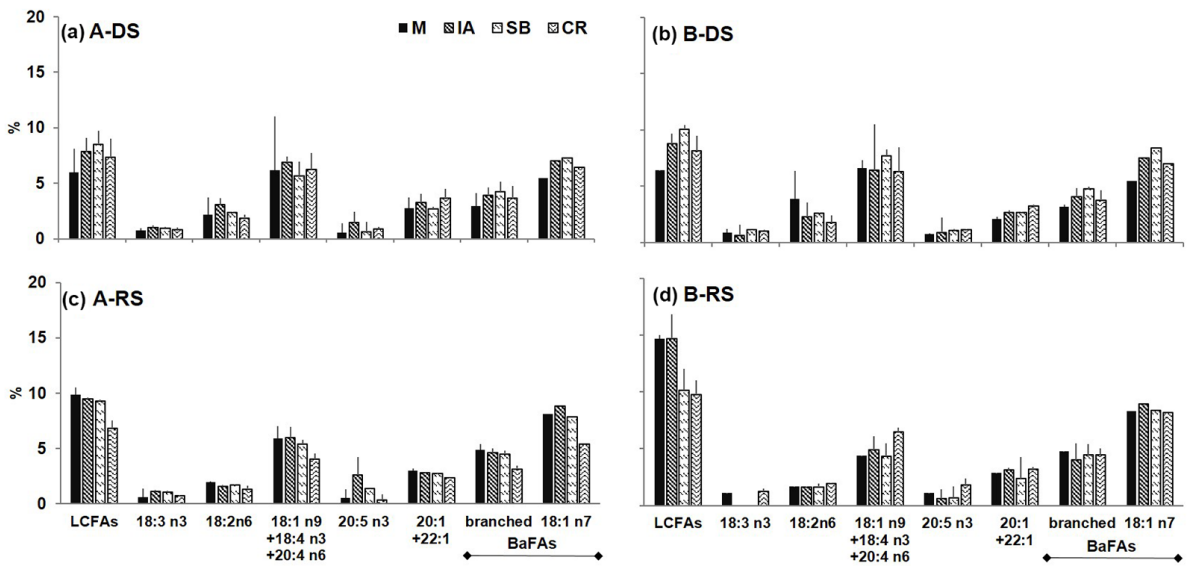

Figure 7. Mean $( \pm \mathrm{SD})$ relative abundance of biomarker FAs (\% of total FAs) in SOM. Selected biomarkers include LCFAs, 18:3 n3 and $18: 2 \mathrm{n} 6$ for mangroves, $18: 2 \mathrm{n} 6$ and $18: 3 \mathrm{n} 3$ for seagrasses, $18: 2 \mathrm{n} 6$ for agricultural runoff, $18: 1 \mathrm{n} 9+18: 4 \mathrm{n} 3+20: 4 \mathrm{n} 6$ for brown macroalgae, $20: 5 \mathrm{n} 3$ for red macroalgae and diatoms, $20: 1+22: 1$ for zooplankton, branched FA, and $18: 1 \mathrm{n} 7$ for bacteria.

the lowest relative contribution to suspended particulate FA profile and were fairly homogeneous in Gazi Bay, except for a few peaks: $18: 3 \mathrm{n} 3$ was null in IA and SB (rainy season transect $\mathrm{B}), 18: 2 \mathrm{n} 6$ peaked in $\mathrm{M}$ (dry season - transect B), and $20: 5 \mathrm{n} 3$ peaked in IA (rainy season - transect A).

\section{Discussion}

\subsection{Organic matter sources}

Elemental and isotopic signatures of mangrove leaves were consistent with documented data from Gazi Bay (Hemminga et al., 1994; Rao et al., 1994) and other mangrove forests (Kristensen et al., 2008). The high $\mathrm{C}: \mathrm{N}$ ratio of leaves (overall, between 100 and 200) is attributable to their senescent status, due to resorption of nitrogen by the mangrove tree during leaf senescence (Woitchik et al., 1997). After the leaf drops onto the soil, consistent nitrogen enrichment versus carbon occurs during decomposition, as a result of a number of physical and chemical transformations (litter breakdown by benthic organisms and microbial remineralisation; Bosire et al., 2005). These processes explain why the $\mathrm{C}: \mathrm{N}$ ratio of mangrove sediments was 1 order of magnitude lower than that of recently fallen senescent leaves, consistent with the literature (Davis et al., 2003; Dunn et al., 2008; Woitchik et al., 1997).

Mangrove leaves showed low carbon isotopic signatures characteristic of $\mathrm{C}_{3}$ vegetation (Bouillon et al., 2008), while both macroalgae and seagrasses were ${ }^{13} \mathrm{C}$-enriched compared to mangroves, and variable along the land-to-sea transects. Indeed, marked gradients were observed, with the most depleted values in the landward station close to mangrove forest, especially in the Kinondo mouth, and the most enriched ones in the seaward station. A similar enrichment was already observed in Gazi Bay and other tropical areas (Hem- minga et al., 1994; Lugendo et al., 2007) and mirrors changes in $\delta^{13} C_{\text {DIC }}$ (Alongi, 2014; Maher et al., 2013). $\delta^{13} C_{\text {DIC }}$ is typically more negative close to mangroves as a result of the intense localised mineralisation of mangrove detritus (Bouillon et al., 2007) and increases seaward due to the higher contribution of oceanic DIC, whose $\delta^{13} \mathrm{C}$ is typically around $0 \%$ (Bouillon et al., 2008). The among-creek variability, with both macroalgae and seagrasses noticeably more ${ }^{13} \mathrm{C}$ depleted in Kinondo Creek than in Kidogoweni, may be due to many factors, but the different settings of the two creeks must account for most of this variability. In particular, the lack of freshwater in Kinondo, coupled with its lower water volume, suggests that terrestrial and mangrove-derived DIC export is less effective when driven by tidal pumping only. Consequently, macrophytes are supposed to use a more ${ }^{13} \mathrm{C}$ depleted DIC in this area than in the other. The higher salinity (Kitheka et al., 1996) and lower $\delta^{13} C_{\text {DIC }}$ in Kinondo waters (Bouillon et al., 2007) support this hypothesis.

\subsection{Export of mangrove organic matter}

Mangrove-derived organic matter contributed greatly to the sedimentary pool at Kinondo Creek and the adjacent intertidal area, as revealed by the great abundance of long-chain fatty acids (LCFAs). Moving seaward, mangrove contribution progressively decreased along the land-sea transect and dropped steeply in the coral reef in both seasons, consistent with Hemminga et al. (1994). This pattern was less evident from isotope mixing models than that observed from FA data. Moreover, in the rainy season, the most likely mangrove contribution to SOM (mode) was higher in the intertidal area adjacent to mangrove forest and then decreased seaward. This pattern suggests that the mangrove area at the Kinondo mouth acted as a retention site where mangrove organic carbon tends to accumulate into sediments. In contrast, freshwater discharge from the Kidogoweni Creek seemed to 
enhance the export of mangrove material, which contributed to the sediment pool relatively more in both the intertidal and seagrass bed areas than in the mangrove stands, as revealed by the higher relative abundance of LCFAs in both IA and SB stations, especially in the rainy season. In addition to the efficient suspended particle trapping by the seagrass canopy (Hemminga and Duarte, 2000), a certain influence of the Mkurumuji River on the organic matter pool of the seagrass bed area cannot be excluded. Indeed, the Mkurumuji River is characterised by high water flows in the south-western part of the bay peaking at $16.7 \mathrm{~m}^{3} \mathrm{~s}^{-1}$ during the rainy season (Kitheka et al., 1996) and a large catchment area covered by dense $\mathrm{C}_{4}$ vegetation and fewer mangrove trees (Bouillon et al., 2007). The combined highest $\delta^{13} \mathrm{C}$ and $\mathrm{C}: \mathrm{N}$ values of SPOM found in the seagrass beds in the rainy season corroborate this assumption, since $\mathrm{C}_{4}$ plants have higher $\delta^{13} \mathrm{C}$ and $\mathrm{C}: \mathrm{N}$ ratio than mangroves (Lamb et al., 2006). This may also have affected mixing model outcomes, which revealed a lower mangrove contribution to both SOM and SPOM in these stations, in contrast to FA results.

The among-site variability observed in Gazi Bay is consistent with the pattern recently described by Adame and Lovelock (2011): mangroves dominated by tidal pumping, like the Kinondo stand, are characterised by bidirectional flows that favour retention of autochthonous material and tight interlinkage between mangroves and adjacent seagrass beds. Higher retention of autochthonous organic matter within a mangrove forest has also been reported in arid mangrove systems in the Arabian Gulf with almost no freshwater input (Walton et al., 2014). On the other hand, riverine mangroves, like the Kidogoweni stand, are dominated by unidirectional flows that favour outwelling (Adame and Lovelock, 2011).

The different dominant vegetation in Kidogoweni and Kinondo creeks (Avicennia marina vs. Rhizophora mucronata; Neukermans et al., 2008) may also affect the magnitude of organic matter export from mangrove forest. Higher export from forests dominated by Avicennia sp., compared to those dominated by Rhizophora sp., has been observed in Brazil and related to different detritus decomposition rates (Lacerda et al., 1995). Moreover, the differing seasonal patterns recorded in Gazi Bay for A. marina and $R$. mucronata litterfall further corroborate this point: A. marina litterfall is higher in the rainy season than in the dry (Ochieng and Erftemeijer, 2002), while $R$. mucronata litterfall is the opposite (Slim et al., 1996). Indeed, the sediment $\mathrm{C}: \mathrm{N}$ ratio in the Kidogoweni stand was almost 2-fold higher in the dry season than in the rainy $(20.8 \pm 0.6$ vs. $11.6 \pm 1.3)$. Given that $\delta^{13} \mathrm{C}$ was constant across time, we may infer a greater contribution of decomposed mangrove litterfall to the sediment in the rainy season. Indeed, decomposition processes are known to reduce the $\mathrm{C}: \mathrm{N}$ ratio, but not $\delta^{13} \mathrm{C}$ (Bosire et al., 2005; Dunn et al., 2008), and are enhanced by a greater supply of nutrients through freshwater flooding during rainfall (Woitchik et al., 1997). In contrast, the sediment $C: \mathrm{N}$ ratio in the Kinondo stand was almost constant across the seasons, as an effect of the lower seasonal variability in freshwater flooding.

In contrast to sediments, mangrove-derived organic matter was recorded in suspended particulate organic matter throughout the whole bay up to the coral reefs, as indicated by the outcomes of mixing models, $\mathrm{C}: \mathrm{N}$ ratio and LCFA relative abundances. This contrasts with previous findings that indicated a limited contribution of mangrove material to the SPOM pool in the southern part of Gazi Bay (Bouillon et al., 2007) and may be due to the timing of sampling, which was carried out mostly during ebb tide. This is confirmed by the similar $\delta^{13} \mathrm{C}$ spatial trend found at ebb tide by Hemminga et al. (1994). Strong downstream ebb currents have been shown to enhance mangrove detritus export and the displacement of mangrove and seagrass waters toward coral reefs (Kitheka, 1997). Despite the buffering role of seagrass beds in preventing a direct connection between mangrove and oceanic waters, we infer that high mangrove export coupled with a high rate of water exchange at spring ebb tide has favoured the outwelling of suspended mangrove material up to the coral reef inner area. The high peaks of mangrove contribution and LCFA relative abundances recorded in the intertidal area adjacent to the Kinondo mouth, especially in the rainy season, reflect the sediment patterns and confirm its role as a retention site for mangrove-derived organic matter.

\subsection{Contribution of other primary producers to the sediment and suspended particulate pool}

Mixing model results revealed a widespread contribution of seagrasses and macroalgae to both sediment and suspended particulate organic matter pools. In particular, the macroalgae contribution was slightly higher than that of seagrasses within the bay and similar or lower in the coral reef. This pattern was overall confirmed by fatty acid results, although caution is needed in interpreting FA findings because biomarkers of primary producers cannot be ascribed solely to one source, as showed by SIMPER results. For instance, both $18: 3 \mathrm{n} 3$ and $18: 2 \mathrm{n} 6$ are combined biomarkers of seagrasses and mangroves (Kelly and Scheibling, 2012; Meziane et al., 2006), and 18:2 n6 is also tracer of agriculture-derived organic matter (Meziane and Tsuchiya, 2002). Hence, their role as seagrass biomarkers in sediment and particulate compartments must be interpreted with caution and may also be limited because their higher lability than LCFAs during decomposition (Mfilinge et al., 2003). Consequently, the higher $18: 2 \mathrm{n} 6$ abundance in SPOM than in SOM suggests the potential influence of agricultural runoff from the sugar plantations surrounding the bay.

With their wide distribution and high productivity as well as their ecological function for marine fauna (e.g. Heck et al., 2008; Gillis et al., 2014), the importance of seagrasses in providing marked carbon input to adjacent and even distant habitats has been widely described. However, relatively few data are available on the productivity and contribution of 
macroalgae to the carbon budget. Moreover, macroalgae are seldom endmembers in mixing models, despite studies on the important trophic and budgeting role of macroalgae associated with mangroves (Koch and Madden, 2001), seagrasses (Heck et al., 2008) and coral reefs (Wernberg et al., 2006). A large quantity of drifting macroalgae, especially Sargassum sp., is transported passively by tides in Gazi Bay (G. Signa, personal observation, 2009; Coppejans et al., 1992) and may account for the large and widespread contribution of brown macroalgae to sediment and, in particular, to the suspended particulate organic matter pool, as revealed by detection of specific fatty acid biomarkers $(18: 1 \mathrm{n} 9+18: 4 \mathrm{n} 3+20: 4$ n6).

Red macroalgae seemed to contribute less than brown macroalgae to the Gazi Bay organic matter pool and it is reasonable because different abundance and biomass of these macroalgae groups were recorded in the area (Coppejans et al., 1992). Nevertheless, it cannot be ruled out that the high biomass of brown macroalgae (with low percentage of 20:5 $\mathrm{n} 3$ ) and the low biomass of red macroalgae (with a high percentage of 20:5 n3) may have a similar effect on sediment and suspended pools. Moreover, caution should be used in dealing with $20: 5 \mathrm{n} 3$, because it is also highly abundant in diatoms (Alfaro et al., 2006; Bachok et al., 2003; Meziane et al., 2006). Moreover, the FA ratio 20:5 n-3 / 22:6 n-3, a marker of diatom/dinoflagellate organic matter, was $>1$ in SOM and $<1$ in SPOM samples, indicating that local production of benthic and pelagic microalgae is an important part of sediment and suspended particulate organic matter respectively (Alfaro et al., 2006).

In contrast, FAs were clear and unambiguous in revealing the marked importance of bacterially derived organic matter (branched FAs and 18:1 n7) in both sediment and suspended particulate pools, indicating a central role for bacteria as mineralisers of organic detritus in Gazi Bay. Cyclopropyl (CY) and hydroxyl $(\mathrm{OH})$ fatty acids have been ascribed to gramnegative bacteria (Kaur et al., 2005) and were also found in both compartments. The abundance of bacteria is not surprising, as they are able to process most of the energy and nutrients in tropical systems (Alongi, 1994). The higher percentage of bacterial biomarkers within the bay suggests a high bacterial biomass in the intertidal and seagrass bed sediments and water column. This is consistent with a previous study carried out in Gazi Bay using $\delta^{13} \mathrm{C}$ analysis of bacteriaspecific PLFAs (phospholipid fatty acids), which found that mangrove carbon was a significant source for bacteria mineralisation in the adjacent seagrass beds (Bouillon et al., 2004). Although branched FAs and 18:1 n7 are ascribed to both anaerobic and aerobic bacteria (Kaur et al., 2005; Meziane et al., 2006), the similar spatial patterns indicate similar response to the environmental conditions of Gazi Bay. As previously found by Meziane et al. (2006) in a subtropical Australian estuary, both markers are probably linked to anaerobic conditions due to high litter accumulation coupled with high temperature. Furthermore, the peaks of 18:1 $\mathrm{n} 7$ recorded in the dry season out of the Kinondo mouth are likely the result of the retention feature of the area. Indeed, a higher increase in 18:1 $\mathrm{n} 7$ than branched FAs was observed after 40 days of decomposition of Rhizophora apiculata leaves (Rajendran and Kathiresan, 2000), co-genus species of $R$. mucronata, the most abundant species living along the Kinondo creek.

\section{Conclusion}

Using elemental and SI signatures, together with FA profiles, this study showed that small-scale variability in the environmental settings of the mangrove forest has a crucial role in influencing the export of mangrove-derived organic matter to adjacent habitats. In Gazi Bay, the short and shallow Kinondo Creek lacked significant freshwater input and, being influenced by tidal pumping only, acted as a retention site where mangrove material accumulated in the forest sediment and the contiguous intertidal area. In contrast, the longer and deeper Kidogoweni Creek, receiving high freshwater input especially in the rainy season, contributed to the export of mangrove material to seagrass beds within the bay. Suspended particulate organic matter revealed a greater contribution of mangrove material up to the coral reefs during ebb tide and confirmed the patterns highlighted for sediments. Moreover, the riverine efflux of the Mkurumuji River, which flows into the southern side of the bay, seemed to contribute more to the suspended particulate pool with $\mathrm{C}_{4}$ vegetal material. In addition, a notable importance of brown macroalgaederived material across the bay was detected, probably due to the high biomass of drifting Sargassum binderi. Fatty acids were particularly well suited to detecting the great bacterial biomass in both the sedimentary and suspended particulate organic matter, suggesting a central role for bacteria as mineralisers of organic detritus in Gazi Bay. These findings confirm the importance of taking into account geomorphological settings and seasonal variability when addressing the question of organic matter export from mangroves in tropical systems. Given the major influence that organic matter exchange across ecosystem boundaries has on organic matter availability and consumption by fauna in trophic webs, future research should be focused on understanding how this small-scale spatial variability may affect trophic dynamics. Further, future research needs to investigate changes in marine productivity with changes in land use activities within and adjacent to Gazi Bay, including mining, seaweed farming, and large-scale sugar plantation.

\section{Data availability}

Data are available and can be requested from the corresponding author (geraldina.signa@unipa.it). 


\section{The Supplement related to this article is available online at doi:10.5194/bg-14-617-2017-supplement.}

Competing interests. The authors declare that they have no conflict of interest.

Acknowledgements. This work was financially supported by the Research Grant "Luigi e Francesca Brusarosco 2008" (Luigi e Francesca Brusarosco Association - Research centre Space, University of Milano - Italian Association of Ecology S.It.E) and by the Flagship Project "RITMARE - Italian Research for the Sea" funded by the Italian Ministry of Education, University and Research. Special thanks to J. Bosire for providing facilities and logistical support during the study. We are also grateful to the people of Gazi who assisted in the fields and to the staff of KMFRI for support during laboratory activities.

Edited by: S. Bouillon

Reviewed by: two anonymous referees

\section{References}

Adame, M. and Lovelock, C.: Carbon and nutrient exchange of mangrove forests with the coastal ocean, Hydrobiologia, 663, 23-50, doi:10.1007/s10750-010-0554-7, 2011.

Alfaro, A. C., Thomas, F., Sergent, L., and Duxbury, M.: Identification of trophic interactions within an estuarine food web (northern New Zealand) using fatty acid biomarkers and stable isotopes, Estuar. Coast. Shelf S., 70, 271-286, doi:10.1016/j.ecss.2006.06.017, 2006.

Alongi, D. M.: The role of bacteria in nutrient recycling in tropical mangrove and other coastal benthic ecosystems, Hydrobiologia, 285, 19-32, doi:10.1007/bf00005650, 1994.

Alongi, D. M.: Carbon Cycling and Storage in Mangrove Forests, Ann. Rev. Mar. Sci., 6, 195-219, doi:10.1146/annurev-marine010213-135020, 2014.

Bachok, Z., Mfilinge, P. L., and Tsuchiya, M.: The diet of the mud clam Geloina coaxans (Mollusca, Bivalvia) as indicated by fatty acid markers in a subtropical mangrove forest of Okinawa, Japan, J. Exp. Mar. Biol. Ecol., 292, 187-197, doi:10.1016/S00220981(03)00160-6, 2003.

Bligh, E. G. and Dyer, W. J.: A rapid method of total lipid extraction and purification, Can. J. Biochem. Physiol., 37, 911-917, doi:10.1139/o59-099, 1959.

Bosire, J. O., Dahdouh-Guebas, F., Kairo, J. G., Kazungu, J., Dehairs, F., and Koedam, N.: Litter degradation and CN dynamics in reforested mangrove plantations at Gazi Bay, Kenya, Biol. Conserv., 126, 287-295, doi:10.1016/j.biocon.2005.06.007, 2005.

Bouillon, S. and Connolly, R. M.: Carbon Exchange Among Tropical Coastal Ecosystems, in: Ecological Connectivity among Tropical Coastal Ecosystems, Springer Netherlands, 45-70, 2009.
Bouillon, S., Dahdouh-Guebas, F., Rao, A., Koedam, N., and Dehairs, F.: Sources of organic carbon in mangrove sediments: variability and possible ecological implications, Hydrobiologia, 495, 33-39, doi:10.1023/A:1025411506526, 2003.

Bouillon, S., Moens, T., and Dehairs, F.: Carbon sources supporting benthic mineralization in mangrove and adjacent seagrass sediments (Gazi Bay, Kenya), Biogeosciences, 1, 71-78, doi:10.5194/bg-1-71-2004, 2004.

Bouillon, S., Dehairs, F., Velimirov, B., Abril, G., and Borges, A. V.: Dynamics of organic and inorganic carbon across contiguous mangrove and seagrass systems (Gazi Bay, Kenya), J. Geophys. Res., 112, G02018, doi:10.1029/2006jg000325, 2007.

Bouillon, S., Connolly, R. M., and Lee, S. Y.: Organic matter exchange and cycling in mangrove ecosystems: Recent insights from stable isotope studies, J. Sea Res., 59, 44-58, doi:10.1016/j.seares.2007.05.001, 2008.

Clarke, K. and Warwick, R.: Changes in Marine Communities: An Approach to Statistical Analysis and Interpretation, 2nd Edn., PRIMER-E Ltd, Plymouth., 2001.

Coppejans, E., Beeckman, H., and De Wit, M.: The seagrass and associated macroalgal vegetation of Gazi Bay (Kenya), Hydrobiologia, 247, 59-75, doi:10.1007/bf00008205, 1992.

Davis, S. E., Corronado-Molina, C., Childers, D. L., and Day, J. W.: Temporally dependent $\mathrm{C}, \mathrm{N}$, and $\mathrm{P}$ dynamics associated with the decay of Rhizophora mangle L. leaf litter in oligotrophic mangrove wetlands of the Southern Everglades, Aquat. Bot., 75, 199215, doi:10.1016/S0304-3770(02)00176-6, 2003.

Dittmar, T., Lara, R. J., and Kattner, G.: River or mangrove? Tracing major organic matter sources in tropical Brazilian coastal waters, Mar. Chem., 73, 253-271, doi:10.1016/S0304-4203(00)00110-9, 2001.

Dittmar, T., Hertkorn, N., Kattner, G., and Lara, R. J.: Mangroves, a major source of dissolved organic carbon to the oceans, Global Biogeochem. Cy., 20, 1-7, doi:10.1029/2005GB002570, 2006.

Duarte, C. M. and Cebrián, J.: The fate of marine autotrophic production, Limnol. Oceanogr., 41, 1758-1766, doi:10.4319/lo.1996.41.8.1758, 1996.

Dunn, R. J. K., Welsh, D., Teasdale, P. R., Lee, S. Y., Lemckert, C. J., and Meziane, T.: Investigating the distribution and sources of organic matter in surface sediment of Coombabah Lake (Australia) using elemental, isotopic and fatty acid biomarkers, Cont. Shelf Res., 28, 2535-2549, doi:10.1016/j.csr.2008.04.009, 2008.

Fry, B. and Sherr, E. B.: $\delta^{13}$ C measurements as indicators of carbon flow in marine and freshwater ecosystems, in: Stable Isotopes in Ecological Research, edited by: Rundel, P. W., Ehleringer, J. R., and Nagy, K. A., 196-229, Springer-Verlag, New York, 1989.

Gillis, L. G., Ziegler, A. D., van Oevelen, D., Cathalot, C., Herman, P. M. J., Wolters, J. W., and Bouma, T. J.: Tiny Is Mighty: Seagrass Beds Have a Large Role in the Export of Organic Material in the Tropical Coastal Zone, PLoS One, 9, e111847, doi:10.1371/journal.pone.0111847, 2014.

Githaiga, M. N., Gilpin, L., Kairo, J. G., and Huxham, M.: Biomass and productivity of seagrasses in Africa, Bot. Mar., 59, 173-186, doi:10.1515/bot-2015-0075, 2016.

Gonneea, M. E., Paytan, A., and Herrera-Silveira, J. A.: Tracing organic matter sources and carbon burial in mangrove sediments over the past 160 years, Estuar. Coast. Shelf S., 61, 211-227, doi:10.1016/j.ecss.2004.04.015, 2004. 
Heck, K. L., Carruthers, T. J. B., Duarte, C. M., Hughes, A. R., Kendrick, G., Orth, R. J., and Williams, S. W.: Trophic Transfers from Seagrass Meadows Subsidize Diverse Marine and Terrestrial Consumers, Ecosystems, 11, 1198-1210, doi:10.1007/s10021-008-9155-y, 2008.

Hemminga, M. A. and Duarte, A. C.: Seagrass Ecology, Cambridge University Press, UK, 2000.

Hemminga, M. A., Slim, F. J., Kazungu, J., Ganssen, G. M., Nieuwenhuize, J., and Kruyt, N. M.: Carbon outwelling from a mangrove forest with adjacent seagrass beds and coralreefs (Gazi Bay, Kenya), Mar. Ecol.-Prog. Ser., 106, 291-301, doi:10.3354/meps 106291, 1994.

Kaur, A., Chaudhary, A., Kaur, A., Choudhary, R., and Kaushik, R.: Phospholipid fatty acid-A bioindicator of environment monitoring and assessment in soil ecosystem, Curr. Sci., 89, 1103-1112, 2005.

Kelly, J. R. and Scheibling, R. E.: Fatty acids as dietary tracers in benthic food webs, Mar. Ecol.-Prog. Ser., 446, 1-22, doi:10.3354/meps09559, 2012.

Kennedy, H., Gacia, E., Kennedy, D. P., Papadimitriou, S., and Duarte, C. M.: Organic carbon sources to SE Asian coastal sediments, Estuar. Coast. Shelf S., 60, 59-68, doi:10.1016/j.ecss.2003.11.019, 2004.

Kitheka, J. U.: Coastal tidally-driven circulation and the role of water exchange in the linkage between tropical coastal ecosystems, Estuar. Coast. Shelf S., 45, 177-187, doi:10.1006/ecss.1996.0189, 1997.

Kitheka, J. U., Ohowa, B. O., Mwashote, B. M., Shimbira, W. S., Mwaluma, J. M., and Kazungu, J. M.: Water circulation dynamics, water column nutrients and plankton productivity in a well-flushed tropical bay in Kenya, J. Sea Res., 35, 257-268, doi:10.1016/S1385-1101(96)90753-4, 1996.

Koch, M. S. and Madden, C. J.: Patterns of primary production and nutrient availability in a Bahamas lagoon with fringing mangroves, Mar. Ecol.-Prog. Ser., 219, 109-119, doi:10.3354/meps219109, 2001.

Kristensen, E., Bouillon, S., Dittmar, T., and Marchand, C.: Organic carbon dynamics in mangrove ecosystems: A review, Aquat. Bot., 89, 201-219, doi:10.1016/j.aquabot.2007.12.005, 2008.

Lacerda, L. D., Ittekkot, V., and Patchineelam, S. R.: Biogeochemistry of Mangrove Soil Organic Matter?: a Comparison Between Rhizophora and Avicennia Soils in South-eastern Brazil, Estuar. Coast. Shelf S., 40, 713-720, doi:10.1006/ecss.1995.0048, 1995.

Lamb, A. L., Wilson, G. P., and Leng, M. J.: A review of coastal palaeoclimate and relative sea-level reconstructions using $\delta^{13} \mathrm{C}$ and C / N ratios in organic material, Earth-Sci. Rev., 75, 29-57, doi:10.1016/j.earscirev.2005.10.003, 2006.

Lee, S. Y.: Mangrove outwelling - a review, Hydrobiologia, 295, 203-212, doi:10.1007/BF00029127, 1995.

Lee, S. Y.: Tropical mangrove ecology: Physical and biotic factors influencing ecosystem structure and function, Aust. J. Ecol., 24, 355-366, doi:10.1046/j.1442-9993.1999.00984.x, 1999.

Lugendo, B. R., Nagelkerken, I., Kruitwagen, G., van der Velde, G., and Mgaya, Y. D.: Relative importance of mangroves as feeding habitats for fishes: a comparison between mangrove habitats with different settings, Bull. Mar. Sci., 80, 497-512, 2007.

Maher, D. T., Santos, I. R., Golsby-Smith, L., Gleeson, J., and Eyre, B. D.: Groundwater-derived dissolved inorganic and organic carbon exports from a mangrove tidal creek: The miss- ing mangrove carbon sink?, Limnol. Oceanogr., 58, 475-488, doi:10.4319/lo.2013.58.2.0475, 2013.

Meziane, T. and Tsuchiya, M.: Organic matter in a subtropical mangrove-estuary subjected to wastewater discharge: Origin and utilisation by two macrozoobenthic species, J. Sea Res., 47, 111, doi:10.1016/S1385-1101(01)00092-2, 2002.

Meziane, T., D'Agata, F., and Lee, S. Y.: Fate of mangrove organic matter along a subtropical estuary: small-scale exportation and contribution to the food of crab communities, Mar. Ecol.-Prog. Ser., 312, 15-27, doi:10.3354/meps312015, 2006.

Mfilinge, P. L., Meziane, T., Bachok, Z., and Tsuchiya, M.: Fatty acids in decomposing mangrove leaves: microbial activity, decay and nutritional quality, Mar. Ecol.-Prog. Ser., 265, 97-105, 2003.

Neukermans, G., Dahdouh-Guebas, F., Kairo, J. G., and Koedam, N.: Mangrove species and stand mapping in Gazi bay (Kenya) using Quickbird satellite imagery, J. Spat. Sci., 53, 75-86, doi:10.1080/14498596.2008.9635137, 2008.

Ochieng, C. A. and Erftemeijer, P. L.: Phenology, litterfall and nutrient resorption in Avicennia marina (Forssk.) Vierh in Gazi Bay, Kenya, Trees-Struct. Funct., 16, 167-171, doi:10.1007/s00468001-0146-2, 2002.

Odum, W. E. and Heald, E. J.: Trophic Analyses of an Estuarine Mangrove Community, Bull. Mar. Sci., 22, 671-738, 1972.

Parnell, A. C., Inger, R., Bearhop, S., and Jackson, A. L.: Source partitioning using stable isotopes: coping with too much variation, PLoS One, 5, e9672, doi:10.1371/journal.pone.0009672, 2010.

Rajendran, N. and Kathiresan, K.: Biochemical Changes in Decomposing Leaves of Mangroves, Chem. Ecol., 17, 91-102, doi:10.1080/02757540008037664, 2000.

Rao, R. G., Woitchik, A. F., Goeyens, L., Vanriet, A., Kazungu, J., and Dehairs, F.: Carbon, nitrogen contents and stable carbon-isotope abundance in mangrove leaves from an eastafrican coastal lagoon (Kenya), Aquat. Bot., 47, 175-183, doi:10.1016/0304-3770(94)90012-4, 1994.

Slim, F. J., Gwada, P. M., Kodjo, M., and Hemminga, M. A.: Biomass and litterfall of Ceriops tagal and Rhizophora mucronata in the mangrove forest of Gazi Bay, Kenya, Mar. Freshwater Res., 47, 999-1007, doi:10.1071/mf9960999, 1996.

Twilley, R. R.: The exchange of organic carbon in basin mangrove forests in a southwest Florida estuary, Estuar. Coast. Shelf S., 20, 543-557, doi:10.1016/0272-7714(85)90106-4, 1985.

Vizzini, S. and Mazzola, A.: The fate of organic matter sources in coastal environments: a comparison of three Mediterranean lagoons, Hydrobiologia, 611, 67-79, doi:10.1007/s10750-0089458-1, 2008.

Walton, M., Al-Maslamani, I., Skov, M., Al-Shaikh, I., Al-Ansari, I., Kennedy, H., and Le Vay, L.: Outwelling from arid mangrove systems is sustained by inwelling of seagrass productivity, Mar. Ecol.-Prog. Ser., 507, 125-137, doi:10.3354/meps 10827, 2014.

Wernberg, T., Vanderklift, M. A., How, J., and Lavery, P. S.: Export of detached macroalgae from reefs to adjacent seagrass beds, Oecologia, 147, 692-701, doi:10.1007/s00442-005-0318-7, 2006.

Woitchik, A. F., Ohowa, B., Kazungu, J. M., Rao, R. G., Goeyens, L., and Dehairs, F.: Nitrogen enrichment during decomposition of mangrove leaf litter in an east African coastal lagoon (Kenya): Relative importance of biological nitrogen fixation, Biogeochemistry, 39, 15-35, 1997. 